\title{
Conservative Christianity and Intimate Partner Violence in Brazil
}

\section{Using Feminism to Question Patriarchal Interpretations of Religion}

\author{
Kim Beecheno | ORCID: 0000-0001-8229-4871 \\ Department of Theology, Centre for Multidisciplinary Research on Religion \\ and Society, Uppsala University, Uppsala, Sweden \\ kim.beecheno@crs.uu.se
}

\begin{abstract}
Based on empirical research in a women's shelter in São Paulo, Brazil, this article examines how 'secular' professionals and service users negotiate conservative Christian faith, gender roles and domestic violence. The article demonstrates how staff use theological arguments with feminist interpretations of religion, in order to better communicate with abused women of faith. A key finding is that both the religious service users and the 'secular' professionals discover it is not religion per se which allows for situations of violence, but rather the patriarchal way in which conservative Christianity is taught in some churches, ultimately functioning as a method of controlling women. Moreover, through feminist consciousness-raising and attention to women's rights, some abused women of faith find ways of negotiating the violence they experience, leading to an understanding of it as both personal and political.
\end{abstract}

\section{Keywords}

Brazil - domestic violence - feminism - Intimate Partner Violence (IPV) Pentecostalism - women's shelters

No, I don't believe in a God who demands human sacrifices. I don't believe in a God who lays waste to a woman's life in order to save a man's soul Floria Aemelia in GAARDER 1998 
This sentence hung in a frame on the wall, one of few decorations in an otherwise lack-lustre counselling room in the Women's Collective, ${ }^{1}$ a centre for abused women in a low-income neighbourhood of São Paulo, Brazil. I later discovered the extract was from the book 'That Same Flower' by Jostein Gaarder (1998), based on a letter entitled Codex Floriae, which is believed to be a legitimate transcription of an original medieval document composed by Floria Aemilia to her lover Saint Augustine, the Bishop of Hippo (4th Century), one of the Latin Fathers of the Christian Church and a famous figure of Western philosophy. Floria was Saint Augustine's concubine for over a decade in Africa and Italy and they had a child together, but Augustine later banished Floria, intending to move on to a socially advantageous marriage. In the end he didn't marry, and chose instead a path of religious asceticism, renouncing all earthly pleasures, hoping to gain eternal life in Heaven. This sentence crystallised Floria's response to her humiliation and rejection, pointing out the hypocrisy of the redemptive power of abstinence, which entailed ruining a woman's life in order for a man to reach Heaven. If the letter really is genuine, then this is probably one of the earliest recorded questionings by a woman of the Church's early views towards the position of women in society (Gaborro 1998). Floria had nothing but contempt for Augustine's faith in a deity who - in her viewplaced the existential and spiritual worth of a man over a woman's (ibid). Why, I wondered, was this sentence hanging in a counselling room in a centre for women experiencing domestic violence?

There is a largely negative view of religion in the literature on organisations combating domestic violence (Beecheno 2019; Bradley 2010; Dobash and Dobash 1998; Lewy \& Dull 2005; Merry 2001; Nason-Clark 1997, 2004; NasonClark and Holtmann 2013; Nason-Clark Fisher-Townsend et al, 2017; Pagelow and Johnson 1988; Plesset 2006; Vilhena 2011), suggesting that religion is presented as a mechanism through which violence against women (VAw) is supported and legitimised. Women with strong religious belief are more likely to stay in an abusive relationship for longer and work harder at saving the marriage than secular women because they believe that a marriage vow made in front of God cannot be undone (Nason-Clark 1997, 2004). Moreover, the message that the family is sacred and that women are held to be the caretakers of the family, responsible for its well-being, can make women more likely to believe that the violence is God's will or their own fault (ibid). Therefore, many feminists believe that VAW is sustained and rooted in the structure and thoughts of patriarchal religion (e.g. Daly 1986; Juschka 20o1; Orozco 2009),

1 The centre and participants have been renamed in order to protect identities. 
although it must be acknowledged that vaw exists across the religious and secular divide. Yet, while belief does not cause abuse, it can contribute to an atmosphere where it is more easily tolerated (Lewy and Dull 2005). These beliefs centre on the idea that God has designated men as dominant, with morally superior judgment, whereas women are meant to be submissive (ibid). With the power of this moral authority comes implied permission for the husband to control his wife and punish her if she disobeys (Pagelow and Johnson 1988). While many women might see their Church as a space of solace and comfort, religious involvement can reproduce domestic distress by reifying traditional gender roles and unequal structures related to gender role expectations are maintained, internalised and naturalised (Chong 2008; Menjívar 2011).

Furthermore, religious women who experience domestic violence can have a particularly difficult time receiving adequate assistance because secular and religious professionals may give conflicting advice (Lewy and Dull 2005; NasonClark 1997; Nason-Clark and Holtmann 2013; Nason-Clark et al, 2017). The authors argue that many secular sources have little understanding of the importance of a victim's religious beliefs and may attribute the victim's abuse in part to her religion. In addition, they argue that religious victims often avoid secular resources and are reluctant to go to counselling because they are afraid their religious beliefs might be misunderstood. Lewy and Dull (2005) find that mental health workers and shelter workers tend to report that the religious beliefs of their clients seem to reinforce passivity and are a deterrent to the effective confrontation of domestic violence and abuse. However, Nancy Nason-Clark and her colleagues suggest that both religious and secular caregivers could work much more closely together (Nason-Clark 1997; Nason-Clark and Holtmann 2013; Nason-Clark et al, 2017).

How faith is addressed and negotiated in ostensibly 'secular' centres which help women experiencing domestic violence remains an understudied area. Brazil is a pertinent place in which to examine this topic, because it sadly ranks among the top 10 countries in the world for lethal vaw and rates of domestic violence are estimated to be very high ${ }^{2}$ (Instituto Patricia Galvão, 2017). Moreover, faith plays an important role in everyday life in Brazil: almost 9o per cent of the Brazilian population agrees that religion is very important in their lives and around 5 o per cent of Brazilians regularly attend some form of worship (G1 2020). Catholicism held a religious monopoly in Brazil since its colonisation until well into the twentieth century. However, Catholicism has now dropped

2 Due to problems including a lack of reporting for domestic violence and discrepancies in the way forms of VAw are recorded by local authorities, the data are likely to reveal far lower levels of VAW than actually exist (Instituto Patricia Galvão, 2017). 
to around 5 o per cent, with people migrating in particular to Evangelical Protestant faiths (30 per cent), most of which are Pentecostal ${ }^{3}$ (G1 2020). Brazil can now claim to be one of the world's largest Catholic and Pentecostal nations simultaneously.

In this article, I examine the way in which the Women's Collective in São Paulo, Brazil, helps abused women of faith overcome situations of violence and the way in which both staff and service users negotiate different understandings of gendered roles and relations. Based on participant observation and in-depth interviews, I identify an explicit focus on addressing conservative Christian-based norms of masculinity and femininity in the centre, which the staff perceive as detrimental in cases of intimate partner violence (IPV) among strongly pious women. However, through the feminist strategies of consciousness-raising and the call to collective action in a safe and uniquely female 'sacred' space, women learn about their explicit right not to be hit (through the Maria da Penha Law ${ }^{4}$ ) and the patriarchal institutions-religious and social — that maintain their subjugation.

I therefore argue that some of the abused women of faith attending the Women's Collective negotiate local gender norms by beginning to question restrictive and conservative gender norms and behavioural expectations, and use the feminist strategy of identifying and questioning patriarchal interpretation of scripture, in order to reduce some of the personal, collective and political forms of violence they experience. Interviews with women of faith and ostensibly 'secular' professionals at the centre reveal the fascinating realisation for both staff and service users that it is not actually religion per se which is the problem, but rather the patriarchal way in which religion is interpreted and used to control women.

3 Evangelical Protestant and Pentecostal doctrines are very similar, although Pentecostals place stronger emphasis on gifts of the Holy Spirit, such as speaking in tongues, miracles and divine healing. Therefore all Pentecostals are Evangelical, although not all Evangelicals are Pentecostal (Pew Forum, 2006). However, in Brazil all non-Catholics are known as and refer to themselves as Evangélicos (Evangelicals).

4 The Maria da Penha law_Lei Maria da Penha (n11.340)—makes domestic violence a crime and gives protection to victims of any sex, including same-sex couples. It is named after the woman who was shot, electrocuted and rendered paraplegic by her husband (Instituto Patricia Galvão, 2017). 

Periphery)

Influenced by feminist mobilisation and outcry over shocking levels of vaw ${ }^{5}$ in Brazil, the state created 'Women's Defence and Community Centres' (Centro de Defesa e Convivencia da Mulher), known by their acronyms, CDCMs. These centres offer psychological help, social welfare assistance and legal advice for women experiencing violence. The centres run workshops and classes aimed at increasing battered women's self-confidence and teach skills such as handicrafts for income generation. Brazil set up its first CDCM in 1990 and there are now 14 in the state of São Paulo although the number of CDCM s and the number of women they can help at one time is low (Instituto Patricia Galvão 2017). Formed in 2004, the Women's Collective was founded after a survey conducted in the area revealed that a disproportionately high number of women appeared to be experiencing forms of domestic violence. ${ }^{6}$ However, salaries are low, local State funding is limited and the centre's survival is precarious as they face a constant battle for funds due to regular budget cuts, linked to varying levels of political will to address vaw.

Moreover, the Zona Leste of São Paulo is well-known for being a low-income, high-crime area. More than 15 per cent of the population live in favelasinformal, low-income communities-and around 8 per cent of people are illiterate (SEADE 2016). In addition, there are high rates of teenage pregnancies, a lack of job opportunities and high levels of urban and criminal violence, including homicide rates far above the São Paulo average (SEADE 2016). At the Women's Collective, staff estimated that at least 6 o per cent of the women at the centre had partners involved in crime. Therefore, abused women in this area suffer multiple and overlapping forms of 'everyday' violence (Scheper-Hughes 1993), including domestic violence and IPV, violence occurring in public spaces due to crime and altercations between gangs and the police, and structural,

5 Violence against Women (VAW) is defined as "any act of gender-based violence that results in, or is likely to result in, physical, sexual or psychological harm or suffering to women, including threats of such acts, coercion or arbitrary deprivation of liberty, whether occurring in public or in private life" (UN declaration on the Elimination of Violence Against Women, 1993). Domestic Violence is a form of vaw and occurs when the perpetrator is known to the woman and with whom she has some kind of relationship, either familial or interpersonal. Intimate Partner Violence (IPV) refers to violence within an intimate relationship, either current or previous.

6 The Brazilian legal definition of domestic violence is a broad definition encompassing physical and sexual violence, as well as verbal and psychological abuse, using threats and defamation to a person's character (Instituto Patricia Galvão, 2017). 
institutional violence due to poor access to services (e.g. health, education), as well as the racial and social stigmas of being poor and black or mixed race. As a post-colonial country, Brazil has developed in conjunction with heavily patriarchal institutions, creating a hierarchically gendered, racialized and class-based society in which poor, black and mixed-race women are the most discriminated against (ibid).

\subsection{Research Methodology and Characteristics of the Service Users}

In order to conduct this study, I spent 7 months from October 2014 to May 2015, empirically examining how three different centres in São Paulo, Brazil, which provide services to women experiencing violence, frame and negotiate the issues of gender, religion/faith and domestic violence. The centres under study include a 'secular' centre with a feminist perspective, (the Women's Collective), a Catholic-based centre (the Family Alliance) and a Pentecostal project (Project Rahab). I used ethnographic methods including participant observation, in-depth interviews and document analysis in the form of leaflets, memos, flyers, and books gained from the study locations. The data for this article comes from the time spent at the Women's Collective, where I conducted 13 indepth interviews, which include $7 \mathrm{x}$ service users ( 5 conservative Pentecostal and 2 Catholic); $2 \mathrm{x}$ social workers ( 1 Catholic, 1 spiritual $\left.{ }^{7}\right), 1 \times$ psychologist (grew up in Pentecostal family, now spiritual), $1 \mathrm{x}$ manager (previously Catholic, now spiritual), $1 \mathrm{x}$ administrative staff (Catholic), $1 \mathrm{x}$ lawyer (spiritual). Participant observation was an especially important tool for listening to group therapy sessions in the CDCM centres, which I attended several times a week throughout the period, as women discussed issues pertaining to violence, gender and religion. I made notes in a notebook while attending the CDCM centres and I reflected on and wrote down my experiences in a fieldnote diary. Regular attendance at the centre allowed people time to get to know me and feel more comfortable in my presence. Ethical approval for the research was sought and obtained from the university institution, as well as from the centres themselves and all the women in the study consented to being part of the study. Analysis of the data was conducted through transcripts and coding data under themes. I used an intersectional, feminist, post-structuralist framework as the analytical approach in order to examine the interrelation between the construction

7 The staff whom I have categorised as spiritual had grown up with Catholic or Pentecostal backgrounds but as adults had turned away from formal religious institutions which they felt was incompatible with their feminist perspectives. However, they still believed in God and sought out personal spiritual experiences. 
of women's subjectivity, the influence of discourse and the relations of power in the centres under study (see Baxter 2003).

Women arrive at the Women's Collective through word of mouth, via referral from health services or from the police, where they are assessed and directed towards the help deemed necessary. A few sessions are one-to-one, but as demand for services is high, much of the therapy is conducted in groups. All the services are free and women can attend (and are encouraged to join) as many of the classes as they want. Therefore, while some service users only come for individual therapy sessions or special events once or twice a month, others come several times a week or some even come every day. According to data supplied by the centre for 2010 to 2013 , the women attending the centre range in age from 18 to $60+$, although the greatest number of women attending in all years were aged 30-39, followed by those aged 18 to 29 , then $40-49$, with a considerable drop occurring in numbers of women seeking help for abuse aged $50^{-}-59$ and $60+$. Over the same period, in almost 80 percent of cases, the perpetrator was the woman's live-in partner, and ex-partner in 7 percent of cases. This is consistent with world data which show that female victims of IPV are predominantly of child-bearing age and that the partner or ex-partner is the most common perpetrator (RHR \& WHO 2013).

Ana, the centre manager, explained that many women at the centre were financially dependent on their partners, and many had not worked for a number of years, because they were the main caretakers of the family. This exemplifies the patriarchal, Christian-influenced culture of Brazil in which women are expected to be responsible for the family and the private sphere of the home, while men go out to work and are the breadwinners. Women therefore suffer structural violence from the patriarchal organisation of state and society which makes women responsible for the family but tends to exacerbate their financial dependence on a male partner. For poor women with little income, mouths to feed, and sometimes few support networks, leaving an abusive partner was harder than for a woman with greater financial resources, as the structural, moral and affective economic impediments can appear insurmountable.

\subsection{The Growth of Pentecostalism in Low-Income, Urban Areas of Brazil}

Religion is also a significant part of life in the Zona Leste. While Catholicism is strong across the country, urban peripheries have the highest number of Pentecostal churches and conversion rates to Pentecostalism among women are high (see Mafra 2001; Mariz and Machado 1997). This is because in low-income areas Pentecostal conversion is sometimes seen as a strategy for dealing with poverty (Stoll 1990) and violence and crime (Mariz and Machado 1997). What is more, some Catholic and Pentecostal churches in Brazil have begun to address 
VAw, although to varying extents (see e.g. Beecheno 2020; Duarte de Souza and Lemos 2009; Teixeira 2018; Vilhena 2011 for specific examples). However, the patriarchal nature of Brazilian Pentecostalism in low-income areas tends is strong, and in general they are conservative, with specific codes of dress (e.g. suits for men and long, modest dresses for women) and expectations of behaviour (e.g. no drinking or listening to non-religious music) for both men and women. Yet Evangelical Protestantism has been demonstrated to reform gender roles by elevating domesticity and responsibility and bringing the male focus back to the home (Birman 2007; Brusco 1995; Mariz and Machado 1997; Teixeira 2018). But it is crucial to point out that such changes are said to occur when the husband also converts to Pentecostalism, meaning that there is no "domestication of men" (Brusco 1995) when male partners do not convert, or when these partners are lapsed.

\subsection{A Feminist Perspective within the Women's Collective}

In Brazil, as in many countries, the word 'feminist' inspires ideas of man-hating and a lack of traditional norms of 'femininity'. Identifying as feminist, particularly in São Paulo's low-income peripheral neighbourhoods which are conservative in relation to ideas of gender roles and relations, requires courage and often elicits negative responses. I found that the staff took an intersectional $^{8}$ approach to feminism, addressing class and race in conjunction with gender, issues that were significant in this low-income, predominantly black and mixed race neighbourhood. The women were introduced to intersectional feminist theories through stories of feminist women of colour from across the Americas, including Sojourner Truth (1797-1883), bell hooks (1952-), Gloria Anzaldua (1944-2004), Sueli Carneiro (1950-) and Lélia Gonzalez (1935-1994). ${ }^{9}$ These feminists served as role models and strategic actors in raising the abused women's feminist consciousness. The histories of black and Indigenous women in the US and Latin America allowed the women to make connections with their own stories of oppression. The women discussed the stigma they felt when they told people they lived in the Zona Leste, with its infamy as a place

8 See Kimberlé Crenshaw, 1996.

9 Sojourner Truth is considered to be one of the first, black, female activists in the US, most famous for her speech Ain't I a Woman? (1863); bell hooks is an American author, feminist, and social activist famous for writing on the intersectionality of race, capitalism, and gender, (see e.g. 1981, 1984). Gloria Anzaldua was an American theorist famous for her work on feminist, Chicana and queer theory (see e.g. 1981, 1987). Sueli Carneiro is considered to be one of Brazil's foremost black, feminist, academics (see e.g.1985, 2011). Lélia Gonzalez was a Brazilian intellectual, politician, professor, anthropologist and human rights defender (see e.g. 1983, 1988). 
of poverty, violence, drugs and crime. They also learned about feminism as a fight for rights and gender equality, linked to race and class, which also links to broader feminist discussions across the Americas, in countries which have a shared history of violent colonisation, slavery and the destruction of Indigenous groups.

The staff held events, such as the monthly 'Lilac Tea' forum, and the weekly 'Social Group', where guests were invited to come and discuss social problems that affected the area. These problems were closely linked to matters of health and the lack of doctors in the local health centres, the lack of crèches, and difficulties accessing welfare benefits (e.g bolsa familia ${ }^{10}$ ). The Lilac Tea and Social Group are examples of spaces in which women were encouraged to understand the overlapping forms of violence they experienced as not simply personal, but also political, and they were encouraged to confront the state by demanding their rights through collective activism. These were therefore consciousnessraising spaces where both women's practical and strategic needs (Molyneux 1985) were aired, and where women were encouraged to examine the subjugation they experienced from the patriarchal organisations and institutions to which they were linked. This shows that the centre's aim was clearly feminist and activist as it had strategic, political and social aims.

The theme of gendered behaviour linked to locally, culturally and religiously imposed norms often surfaced as an important factor in spaces such as the Lilac Tea. During one group session, Ana described the Lilac Tea as, "a space for gathering strength, of empowerment and respect for the rights of women". She said: "the Lilac Tea is a space for an alternative education because formal education oppresses women [due to its lack of gender focus], it's a moment for looking up, not for submission." This kind of emotive language "looking up" and "submission" is interesting because of its religious overtones and it seemed clear that Ana used such language in order to provoke the women. Vera, a regular service user in her 4 os responded:

You watch television and it seems like all they do is kill women ... How much longer can this carry on? We don't want to be submissive, to bend our heads and say Amen to everything, because we're equal. Even before being women, we are human, with the same desires, the same desire to fight ... the same desire to win ... we're human too, not just women Vera, Service User, 17/04/2014 
Vera's quote underscores the tension some of the women clearly felt in relation to gender-based norms that encouraged female submission to men, and ultimately could lead to the legitimation of vaw. Many Brazilian Pentecostal churches tend to emphasize female submission to their male partners, and Vera's frustration with such conservative, religiously-based gender norms was palpable. However, this comment also demonstrates the way in which discussions around IPV, human rights and women's rights at the centre allowed her to express these frustrations and link some of the gender-based inequalities and injustices to the institutions around her, including conservative, patriarchal Pentecostal Churches.

These frustrations were echoed by other women at the centre. For example, 38 year-old Lourdes, a Pentecostal woman who had been coming to the centre for three years due to physical and mental abuse at the hands of her husband, said:

In Church, the pastor's wife tells us we have to look after our husbands, even when they want something ... you know ... physical [sex] and we don't. She says we have to do that even when we don't want to, because it's women's role to serve men and that's what we were born to do. I used to believe that until I began to understand our rights, and today I don't believe that anymore

Lourdes, Service User, 30/04/2015

Research has demonstrated that pastors' wives have considerable influence in churches and communities, and within Pentecostal churches women often turn to pastors' wives for help and advice (Birman 2007, Teixeira 2018). However, this case - unlikely to be unique-exemplifies the extent to which patriarchal and unequal teachings on gender roles and relations are emphasized and reaffirmed by women themselves, even reinforcing potentially erroneouslyinterpreted concepts such as a 'woman's duty' to serve men and provide sexual relations for her husband, even when she does not want to. Teachings such as these are even more detrimental for women who experience IPV and yet are taught that they must serve and even (sexually) pleasure their abuser. This highlights how gendered, self-regulating behaviour is encouraged in the home through patriarchal teachings within the Church—regardless of whether such ideas are religiously mandated or not.

Estefania, a Pentecostal woman from the popular Assembly of God Church, who had also attended the centre for several years due to IPV from her husband, explained how conservative Pentecostal beliefs around gender and sexuality had affected her perception of others outside the home, as well as her 
behaviour towards her husband inside the home, until she learned new ideas based on the feminist teachings at the Women's Collective:

I love the Lilac Tea: we learn so much, about illness, about issues ... mainly about women, that's what we talk about most. Before, some of us had prejudices against certain people, like homosexuals, but here we learn that everyone should be treated equally. Even though I'm Evangelical, now I accept the person as they are. Before, I thought the idea of homosexuality was disgusting, but now I've changed. I'm embarrassed

Estefania, Service User, 30/04/2015

Estefania explained how her beliefs around gendered norms of behaviour and gendered identities and sexualities were linked to conservative Pentecostal norms she had learned in church, but her perception of these changed the longer she spent at the Women's Collective. Estefania said she still attended church because her faith in God had not changed. However, she said she now felt indignant when she heard something full of prejudice in church itself. Estefania explained that her concept of gender roles and relations had changed since attending the centre:

Here, I learned how to deal with the aggressor. That's important, how to defend oneself verbally (...) you have to make him realise that he has to respect the woman and respect himself and there has to be dialogue. He has to learn that we weren't born to be men's servants, like his mother, that the chores have to be divided, that we have to be equal ... Oh, my gosh I've changed so much! I was brought up in the Church, all I knew was that I had to bow my head, I had to cry and accept it silently but not today!

Estefania, Service User, 3o/o4/2015

Estefania's discourse shows how a patriarchal, conservative gender-based discourse focusing on the concept of a well-behaved, obedient and silent woman is reinforced in some churches, which led her to believe that she had to accept what her husband said or did, even when it hurt her, because he was the male authority. Yet at the Women's Collective, Estefania appears to have learned techniques to deal with verbal and physical aggression and she has consequently grown in confidence. Estefania learned about women's rights and in particular the law against domestic violence (Maria da Penha law), which she says led to change in her relationship and helped to reduce the IPV she experienced: 
One day I said to him: "Either you change, or we have a problem". I said it very clearly and explained that if it wasn't good for him then he could leave. Thank God, he changed (...) I wouldn't say it's perfect but we're managing to live together ok and it's so helpful to know there is somewhere that supports us. It's a bit intimidating for him, knowing there are lawyers and social workers and psychologists on my side, he gets annoyed when he thinks about the Maria da Penha Law

Estefania, Service User, 3o/o4/2015

A similar story was echoed by Lourdes:

My husband hates that I come here and he hates the women who work here, he says they're all feminists, but he's too scared to forbid me to come because now we know the law is on my side. He says, "this bloody Maria da Penha, it's like she's in my house ..." Before, I didn't trust the police but now I know my rights and I know the girls from the Women's Collective will support me

Lourdes, Service User, 30/04/2015

Lourdes, Estefania and their partners now understand that the Maria da Penha law criminalises domestic violence which can lead to a prison sentence for the perpetrator. The knowledge about their rights, and the legal and social support they know is available, appears to have increased the women's confidence, while their husbands' have become more intimidated about their use of violence, meaning that physical violence in the home appears to be somewhat reduced. The women are therefore able to resist some level of IPV both individually and as part of a collective group at the centre. In the following section, I examine the interaction between professional staff and women of faith more closely.

\section{3 \\ Interactions between 'Secular' Staff and Abused Women of Faith}

Many strongly pious women have views that clash with feminist views on femininity, such as the role of the dutiful wife to pray for a husband who has lost his way, the importance of female submission to her husband or the belief that their experience is God's will. This view was supported by the staff at the Women's Collective, who believed that women of faith were often powerless to disentangle themselves from a marriage which they believed to be ordained by God. The story below — one of many — exemplifies such a case, and I use it to 
highlight the alternative ways the secular professionals found to interact with women whose conservative Christian faith was strong.

\subsection{Using Discursive Techniques to Address Faith and IPV}

According to Adriana, the abuse she experienced from her husband began with small prohibitions, which she would accept in order to appease him, such as no longer listening to music in the home or singing. But the prohibitions grew, and she felt forced to accept more and more until finally it meant that she was not allowed to leave the house and visit her family. The wake-up call came when he beat her severely and she realised that she was in danger:

My husband is a local policeman (Guarda Municipal). He's a very serious man, he doesn't like to socialise, to go out, visit family. He doesn't let me see my family. One day, it was Christmas, I told him that I was going to see my family and he could stay home alone. That's when he hit me, grabbed me by the hair, threw me on the floor and beat me. He said that I couldn't go. I became very scared of him, so one day I went to a friend's house and I'm still there, a year later. Every time I go back he threatens me, I'm too scared to stay. But I can't separate from him, he's the man I chose to marry. My choice was blessed by God, and when we were dating Jesus revealed to me that he was the man of my life and I believe that God chose him for me. I can't leave him

Adriana, Service User, 17/04/2014

Adriana said she did not feel capable of denouncing her husband to the police, taking legal action against him or even divorcing him, because, in her words, God had chosen him as a husband for her. His position of dominance was also reinforced by his status as an official, male representative of the state, (a local policeman), which made it even harder to denounce his abusive and controlling behaviour. A committed Pentecostal, Adriana said she had discussed the situation with her pastor and the pastor's wife. They told her to pray and that if she prays hard enough she will be given the answers she needs. This echoes Menjívar (2011) who found that women experiencing violence were told to pray, endure and be patient, but that this resulted in the normalisation of feelings of responsibility and culpability about their situation and led to the normalisation of the suffering they experienced.

Edna, the centre's psychologist who had grown up in a Pentecostal home herself, explained that she used religious language to communicate with strongly pious women such as Adriana. She used discursive techniques to get religious women thinking differently: 
If a woman tells me that she must stay with her husband because Jesus chose him for her, then I say "ok, but right now you're suffering and you still want to stay with this man". The women always say, "but Jesus says we must stand firm, pray, that a woman is the column of the house, we need to watch over it and not give up". So, I say "well, that's a real sacrifice, can you see this sentence on the wall?"11 Read this sentence to me". They read it and I ask them: "do you think that God demands the sacrifice you are making? Do you think He's happy that you are being beaten up and forced to have sex when you don't want to? do you really think He wants you to bleed, with no teeth in your mouth because they've all been knocked out?"

Edna, Psychologist, o5/12/2014

Edna encouraged the women to question what God would want, which was a discursive technique that fitted with the women's religious values, allowing them to begin questioning their suffering and whether the abuse they experienced was really mandated by God. Edna believed that teaching women gender equality and opening their eyes to patriarchal forms of control was important, because it could help to break down traditional gender stereotypes that contributed to women's submission. She wanted women to find a voice, to regain their personality and autonomy. "Women need to be taken out of this position of saviour, provider and maintainer of the home and in a subjective sense, they need to place themselves in their own lives." For Edna, this translated into a loss of agency for the women and control over their own lives. Authors such as Saba Mahmood (2005) have demonstrated that female self-sacrifice for the improvement of a partner or the family is agentic in itself; however, choosing piety and submission in a healthy relationship is very different from submitting oneself to a partner's violence because you believe that is mandated by God.

\subsection{Re-interpreting Scripture from a Feminist Perspective}

Marcia, the social worker, explained that she used to find it difficult to work with women whose faith was very strong, but she had learned to develop similar techniques of questioning religious interpretation from a feminist perspective. Marcia had grown up in the Zona Leste and taken part in youth activities in the Catholic Church. "They had a really cool angle at the time based on Liberation Theology. There was so much discussion on the fight against social inequality, the oppressed, but then that ended". ${ }^{2}$ Marcia left the Church and at university became part of the student welfare movement where she became an activist.

11 Referring to the sentence highlighted at the beginning of the chapter.

12 After the Second Vatican Council in 1962-1965 and the Latin American bishop's meeting 
She saw faith as both women's "ally" and their "executioner". She explained that during her sessions, religion often came up as an important reason why the women remained in violent relationships. Marcia felt that this was reinforced by priests, pastors and even churchgoers, who all reminded the women they had to have faith and they had to believe that things would change. According to Marcia, in some cases the pastors went as far as telling women that the violence was the women's fault, believing it had to be linked to something the women were doing wrong, an attitude which is supported by other researchers, e.g. Nason-Clark, 1997, 2004, 2017. According to Marcia, this focus on women's behaviour left them trapped in their situation and unable to make positive changes:

Whenever I'm doing a session, there are always some women who have a really strong faith and they say, "God is going to help me, the way things are, God will help me." But you have to make her see that she needs to act on what's happening, she needs to go beyond faith and act.

Marcia, Social Worker, 17/04/2015

Marcia was keen to find ways to connect with religious women because she believed that the centre had to work for all women experiencing violence, and not neglect those who had different beliefs than her own. Marcia's difficulty was that the interventions and techniques she suggested to the women, such as separating physically for a time, often did not work for devout Christian women. However, she had found writings by Catholics for Choice (CFC) a Catholic prochoice organisation, as well as writings by feminist pastors who "do really cool analyses of religion and make great debate". In the process, Marcia discovered that she herself had perhaps been overly radical, initially believing that women had to turn away from religion in order to overcome violence. Marcia explained that she had learned to be more tolerant because she now understood that religious belief and practice were important in the lives of some women. One

in Medellín in 1968, the Catholic Church's doctrine and organisational practices changed to include greater emphasis on lay participation, with a focus on a 'preferential option for the poor' and actions to benefit the poorest and most marginalised sectors of the population (Htun 2003). This was the basis of Liberation Theology. It played an important role in the growth of many social and political movements towards the end of the dictatorship and the beginning of democratic construction in Brazil (ibid). However, Pope John Paul II, elected in 1978, chose to counter Liberation Theology and replace its popular and participatory approach with a 'Polish model' that emphasised unity, hierarchy and discipline. A new era of Charismatic Catholicism therefore was ushered in, focused on a personal relationship with God and less on social activism (ibid). 
of the techniques Marcia had developed was reading the Bible with religious women and discussing the importance of interpretation. Marcia realised that in order to reach out to women of faith, just like Edna, she needed to speak to them in language that made sense to them. In discussing the Bible, she could offer feminist interpretations and deconstruct some of the interpretations that she argued legitimised vaw due to flawed, patriarchal readings of the Bible:

We read passages and from that you can deconstruct some of the things that are strongly related to interpretation of text. We read the Virtuous Woman, extracts from the Book of Esther and other bits that suggest putting oneself in the place of the subaltern. I help the women to see how the text is based on interpretation and that the so-called 'woman's position' is really an interpretation of where women are placed.

Marcia, Social Worker, 17/04/2015

Marcia recounted the case of Viviane, a devoutly Pentecostal woman severely abused by her husband, and how discussions on the passages Viviane brought in for reading led her to a new understanding. "She would reflect and say to me, 'it's true, isn't it Marcia, look at how the interpretation of the text is important!' and she even began to question her pastor about things in the text, saying to him 'I don't think it's quite like that." Although concerned about involving herself in someone else's spirituality, Marcia felt she had found a way to continue conducting her social work in a language and context that women of faith women could relate to. This helped both Marcia and the abused women she worked with understand that spirituality, faith, and religious practice were not inextricably linked with violence in a relationship.

In this article, I have brought to light new insights on the ways in which both abused women and professionals negotiate restrictive gender-based conservative Christian norms. For the staff, working with abused women of faith from within the Christian framework to which they adhered (Pentecostalism and Charismatic Catholicism), allowed for far better communication between 'secular' professionals and women of faith. Discussions around some aspects of conservative Christian thought and developing an understanding that there are other ways of interpreting texts, allowed abused pious women to assess their position in a different light. The feminist focus of questioning the social construction of women's place in society led the abused women to a grow- 
ing understanding of the different forms of gendered oppression they suffered. Women did not have to give up their faith by any means, but they began to identify when it was being used as a patriarchal method of control. They therefore learned that having a more equal and non-violent relationship could be consistent with their faith.

My research brings new knowledge to the literature on interactions between ostensibly 'secular' support centres and abused women of faith, as the Brazilian example demonstrates that they can work together, but that an understanding of women's faith is necessary. Many of the staff were familiar with the Christian context and belief systems within which the women were brought up. This shared understanding allowed the professionals and the abused women of faith to communicate with each other, in religious terms and language that were familiar to both parties. The staff did attribute the women's suffering in part to the women's religious faith, which they believed exacerbated women's inability to act on their situation. But by focusing on examining questions of gender and patriarchy, both the staff and the abused women learned that it was not belief per se that was the problem, but instead the masculinist way in which the Bible was interpreted within certain churches. The professionals also saw that faith brought strength and hope to many abused women and I demonstrated that the staff were not entirely secular in their own beliefs: they often had a personal level of spirituality but did not attend Catholic or Pentecostal churches due to the structural and symbolic violence they felt they experienced through patriarchal, gender-conservative ideology relating to gender and women's roles in society. This personal spirituality links into Grace Davie's concept of 'believing without belonging' (1990). Therefore, through feminist consciousness-raising, abused women began to see a difference between their faith and the use of religion as a mechanism through which female submission and norms of gendered roles, relations, behaviour and sexuality were normalised in society. More secular contexts such as Canada and the UK could learn much from the approach towards religion being taken in Brazil.

\section{Acknowledgments}

I am very grateful to the staff and service users of the Women's Alliance who allowed me to spend time there and shared their stories with me. I would also like to thank the anonymous reviewers for their helpful comments on the article, and I would like to thank King's College London for financially supporting this research. 


\section{References}

Baxter, J. 2003. Positioning Gender in Discourse, Palgrave Macmillan.

Beecheno, Kim. 2019 Faith-Based Organisations as Welfare Providers in Brazil:The Conflict over Gender in Cases of Domestic Violence, Social Inclusion, 7:2, 14-23.

Beecheno, Kim. 2020. 'Project Rahab: Pastoral Power, Pentecostal Conversion and the Disciplining of Femininity and Race in Cases of Domestic Abuse', in: Ralph W. Hood Jr. \& Sariya Cheruvallil-Contractor (eds.), Research in the Social Scientific Study of Religion (RsssR), Volume 31: A Diversity of Paradigms, Leiden \& Boston: Brill, 470486.

Bradley, Tamsin. 2010. Religion as a Bridge between Theory and Practice in Work on Violence Against Women in Rajasthan, Journal of Gender Studies, 19:4, 361-375.

Birman, Patricia. 2007. 'Conversion from Afro-Brazilian Religions to Neo-Pentecostalism: Opening New Horizons of the Possible', in Timothy Steigenga and Edward L. Cleary (eds.) Conversion of a Continent: Contemporary Religious Change in Latin America, New Brunswick, New Jersey and London: Rutgers University Press, $115^{-132 .}$ Chong, Kelly. H. 2008. Deliverance and Submission: Evangelical Women and the Negotiation of Patriarchy in South Korea, Asia Centre: Harvard University.

Daly, Mary. 1985. Beyond God the Father, Towards a Philosophy of Women's Liberation, London: The Women's Press.

Davie, Grace. 199o. Believing without Belonging: Is this the future of religion in Britain? Social Compass, 37:4, 455-469.

Dobash, R. Emerson and Dobash, Russell P. 1980. Violence Against Wives: A Case Against the Patriarchy. London: Open Books.

Duarte de Souza, Sandra and Carolina. T. Lemos, 2009 A casa, as mulheres e a igreja: Gênero e religião no contexto familiar, São Paolo: Fonte Editorial.

Gaarder, Jostein. 1998. That Same Flower: Floria Aemilia's Letter to Saint Augustine, Farrar Straus \& Giroux.

Gaborro, Allen. 1998. Book Review: That Same Flower by Jostein Gaarder, accessed 14 May 2018, available at: http://www.eclectica.org/v2n6/gaborro_that_same_flower .html.

G1. 2020. 50\% dos brasileiros são católicos, 31\%, evangélicos e $10 \%$ não têm religião, diz Datafolha, G1 news service, accessed January 5 2020, https://g1.globo.com/politica/ noticia/2020/o1/13/5opercent-dos-brasileiros-sao-catolicos-31percent-evangelicos -e-1opercent-nao-tem-religiao-diz-datafolha.ghtml.

Htun, Mala. 2003. Sex and the State: Abortion, Divorce, and the Family Under Latin American Dictatorships and Democracies, Cambridge University Press.

Instituto Patricia Galvão. 2017. 'Dossiê Violência contra as Mulheres', accessed April 15 2019, available at: http://www.agenciapatriciagalvao.org.br/dossie/.

Juschka, Darlene. M. 2001 'Introduction: Feminist Discourses and the Study of Religion', 
in Darlene M. Juschka (ed.) Feminism in the Study of Religion: A Reader, London and New York: Continuum.

Lewy, Colleen S. and Dull, Valerie T. 2005. The Response of Christian Clergy to Domestic Violence: Help or Hindrance?, Aggression and Violent Behavior 10, 647-659.

Mariz, Cecilia L., Machado, Maria das Dores C. 1997. 'Pentecostalism and Women in Brazil', in: Edward Cleary and Hannah Steward-Gambino (eds.) Power, Politics, and Pentecostals in Latin America, Harper Collins.

Mafra, Clara. 2001. Os evangélicos (Descobrindo o Brasil), Editor Zahar.

Mahmood, Saba. 2005. Politics of piety: The Islamic revival and the feminist subject. Chicago: University of Chicago Press.

Menjívar, Cecilia. 2011 Enduring Violence: Ladina Women's Lives in Guatemala, Berkeley, Los Angeles, London: University of California Press.

Merry, Sally. E. 2001. Rights, Religion and Community: Approaches to Violence against Women in the Context of Globalization, Law and Society Review, 35:1, 39-88.

Molyneux, Maxine. 1985. Mobilisation without Emancipation? Women's Interests, the State, and Revolution in Nicaragua, Feminist Studies, 11:2, 227-254.

Nason-Clark, Nancy. 1997. The Battered Wife: How Christians Confront Family Violence, Louisville, Kentucky: Westminster John Knox Press.

Nason-Clark, Nancy. 2004. When Terror Strikes at Home: The Interface between Religion and Domestic Violence, Journal for the Scientific Study of Religion, 43:3, 303310 .

Nason-Clark, Nancy. \& Holtmann, Catherine. 2013. 'Thinking about Cooperation and Collaboration between Diverse Religious and Secular Community Responses to Domestic Violence', in Winnifred F. Sullivan and Lori G. Beaman, (eds.) Varieties of Religious Establishment, London: Routledge.

Nason-Clark, Nancy., Fisher-Townsend, Barbara., Holtmann, Catherine., and McMullin, Stephen. 2017. Religion and Intimate Partner Violence: Understanding the Challenges and Proposing Solutions, Oxford Scholarship Online.

Orozco, Yuri. P. 2009. 'Violência, Religião e Direitos Humanos', in Yuri P. Orozco (ed.) Religiões em Diálogo: Violência contra as Mulheres, Católicas Pelo Direito de Decidir, 131-140.

Pagelow, Mildred, D. and Paul Johnson. 1988. 'Abuse in the American Family: the Role of Religion, in Abuse and Religion', in Anne, L. Horton and Judith Williamson (eds.), When Praying Isn't Enough. Lexington: Lexington Books, 1-12.

Pew Forum. 2006. 'Spirit and Power, A 10-Country Survey of Pentecostals, Executive summary', accessed 5 February 2018, available at: http://www.pewforum.org/ Christian/Global-Christianity-exec.aspx.

Plesset, Sonia. 2006. Sheltering Women: Negotiating Gender and Violence in Northern Italy. Stanford, CA: Stanford University Press.

Reproductive Health and Research (RHR) \& World Health Organisation (WHO). 2013. 
'Global and regional estimates of violence against women: prevalence and health effects of intimate partner violence and non-partner sexual violence', Geneva, Switzerland, wHO. Available at: https://www.who.int/reproductivehealth/publicati ons/violence/9789241564625/en/.

Scheper-Hughes, Nancy. 1993. Death without Weeping: The Violence of Everyday Life in Brazil. Berkeley: University of California Press.

Fundação Sistema Estadual de Análise de Dados (SEADE). 2016. 'IMP: Informações dos Municípios Paulistas', Portal de Estatísticas do Estado de São Paulo, accessed ${ }_{13}$ October 2018, available at: http://www.imp.seade.gov.br/frontend/\#/perfil.

Stoll, David. 199o. Is Latin America turning Protestant? The Politics of Evangelical Growth, Berkeley, Los Angeles and Oxford: The University of California Press.

Teixeira, Jacqueline. 2018. 'A conduta universal: governo de si e políticas de gênero na Igreja Universal do Reino de Deus São Paulo', PhD Thesis, University of São Paulo.

Vilhena, Valeria. C. 2011. Uma Igreja Sem Voz: Análise de Gênero da Violência Doméstica entre Mulheres Evangélicas: São Paolo, Fonte Editorial. 